\title{
Do Teachers of Lecturers need to write Children Literature?
}

\author{
Rina Ratih \\ Universitas Ahmad Dahlan Yogyakarta \\ rinaratihuad@yahoo.com
}

\begin{abstract}
Appropriate texts for children may contribute to support their self-development in many aspects. Text selection should consider cultural values, for children do not grow up in an empty culture environment. Children's literature are mostly the creation of men of letters. Thus, do teachers or lecturers need to participate in creating more works for children? Based on the problem, this study aims at developing a model of children's literature that is adjusted to their development stages. The research belongs to descriptive qualitative research, employing Brady's theory on children developmental stages and Corry Layun Rampan's writing techniques for children's literature. It also uses literature review and creative process. The results are a work of children's literature entitled "Rambut Keriting Surti." The work can be further used as a reading model for elementary school students, at the age group of 10-12 years old. The story was written by considering the children's development stages, particularly emotional, intellectual, and personal development.
\end{abstract}

Keywords-children's literature; children development; story model.

\section{INTRODUCTION}

Children literature is always an interesting subject, especially those that are related to the reading materials. Children literature influences the growth and character development of the children. Edwards (2004) proposes that appropriate literary text contributes to develop children's characters. Thus, the process of selecting the text should consider cultural factor because children grow and learn in a cultural vacuum. Culture, in this context, includes customs, verbal and non-verbal behavior, and others as demonstrated by the family members or the environment.

Riris K. Toha Sarumpaet (2003) explains that children literature, which includes children stories, means literary work that are written for children, that talks about children and the influential factors around them, and that can be enjoyed only by children with the help and assistance of the adults. In line with the idea, Nurgiyantoro (2005) suggests that children literature is a work that represents the emotion and experience of the children through the children ${ }^{\text {es }}$ point of view.

Children literature may cover poems, prose, play, that are created through imagination using the language as the media. It reflects the imaginary world, yet containing aesthetic values (Resmini, 2006). Recent works for children can easily found in the bookstores. Nowadays parents are eager to buy books for their children. However, can the text quench their thirst, or are suitable with their developmental stage? Do a teacher or a lecturer need to write children "s literature? The two questions need to be answer.

Teachers hold the responsibility of selecting reading materials for the children at school. Parents are responsible for selecting the text for children at home. As teaching materials, classroom teachers focus more on the materials included in the text. Reading materials in the library are treated as reinforcement. Most often, parents buy books for their children without reading them first. Most of them believe that as long as the books are for children, they are good for them. What matters is only the children's happiness when receiving the books. Parents do not bother themselves to learn about the book or to know whether the books are suitable for their childrenes development.

Several researchers have discussed the problem related to children's literature. Among them are Sugihastuti, Burhan Nurgiantoro, and Rina Ratih. Sugihastuti (2015) emphasizes children es literature in the form of television programs. She states that the shows imported from other countries spread in many TV stations and present cultural complexity that, to some extent, are not suitable with our national culture. Indeed, the psychological content deviates the children 's psychological normality. Therefore, children's literature comes as a help in this case. The problem has challenged parents to be wiser in taking care of their children at home, especially when they are watching television. Sugihastuti (2015) also discusses the significance of children es literature by analyzing the character education values in the collection of short stories entitled Lebah Lebay di Taman Larangan which was written by Rina Ratih.

Burhan Nurgiyantoro (2005) concerns with the children's developmental stages and the selection of children $\mathrm{s}$ literature. He states that one of the helps for the children is by providing relatable reading materials which are appropriate for their developmental stages. Appropriate selection will have positive impact to their developmental stages. One of the impacts is the increasing awareness of the children to read, for they gain more knowledge, experience, and entertainment. It is expected that the impact will help them to be better adult.

Rina Ratih (2016) studied the creative process of writing children ses stories, fable, and folklores, as well as the difficulties found by beginner writers. According to her, writing is the maturity process of the writeres imagination, 
emotion, and intellect. Writing children stories, fables, or folklores, are the commitment and love of individuals to children's literature. In doing so, these writers take several steps. First is the mastery of writing techniques, writing mechanics, dictions, and so on. Second is the willingness to read other writers ${ }^{\text {ee }}$ works to find references. And the third is the ongoing practice of writing.

To compare, Sugihastuti and Nurgiyantori concludes that providing appropriate reading materials for children are significant for their developmental stages. Parents are also responsible for selecting the reading materials at home. Meanwhile, RIna discussed the creative process of writing. They have studied about the children 's literature, but none has discussed the significance of teachers or lecturers to write children "s literature. Therefore, do teachers or lecturers need to do so? This study aims at resulting children's literature model which have been adjusted to the children 's developmental stages. The study uses Brady theory on children's developmental stages and Corry Layun Lampean 's theory on children's story writing. The research employs library research and creative process. It is expected that the research will contribute to the enrichment of reading materials to be used in the teaching of literature for Elementary School.

\section{METHODS}

There are four grounds of testing children's developmental stages, as proposed by Brady (in Saxby and Winch, 1991). First is children 's interest in reading materials. Second is the understanding of children "s development, both general and particular. Third is the understanding of children's developmental stages that helps to select the reading materials. Fourth is the understanding of selecting reading materials that have are adjusted to the children 's developmental stages.

Each stage has different characteristics. The stages include intellectual, moral, emotional and personal, language, and story concept development (Brady, 1991; Huck et al, 1987). The different characteristic of each stage does not mean that they are against each other. Instead, they simultaneously help to develop the children ${ }^{\text {es }}$ maturity process. There will be logical consequence of the difference combined with the relevant reading text as well as the various stages.

Children of elementary school, ranged from 7 to 11 years old, are in the operational stage (the concrete operational, 7-11 years old). In this stage, children can understand the logics in steady way. Children 's characteristic at this period are (1) the ability to classify object according to its general nature; (2) the ability to arrange things in the correct order, such as by alphabet, numeric, and size; (3) the ability to improve the imagination of the past and future; and (4) the ability to think argumentatively and to solve simple problems. In the last stage, they tend to get ideas like adults, but they have not been able to think about abstract ideas. Their thinking is limited to concrete situation.

Books that are relevant and will have possible implications to the children "s developmental stage are those having the following characteristics. First, they are narrative or explanatory text written from the simplest to the most complex logical sequence. Second, they present simple stories, either by the plot, the way the plot is presented, or by the number of characters. Third, they provide various illustrations, sometimes simple diagram or model. Fourth, they are narrative text presenting the narrator telling the stories, or stories that make the children project themselves to particular time and place. They are books for children who can be engaged in the characters ${ }^{e e}$ thought or in solving the problem faced by the protagonist characters or in predicting the plot of the stories.

Writing fiction is an individual's creative process. Writing children stories means creating a world for children through the author's imagination. Fiction consists of intrinsic elements: theme, characters, plots, setting, title, point of view, style, and tone. In her writing entitled "Dasar-dasar Penulisan Cerita Anak," Rampan (2003) explains that children stories are simple yet complex ones. The characteristic is marked by standardized discourse, highly qualified, but simple and communicative. Besides, the shift from adult's way of thinking to the thinking, soul, and characteristics of the children will be more interesting. In other words, children stories should talk about their world with all the aspects that influence them.

\section{FINDING AND DISCUSSION}

Based on the proposed problems, „Does teachers or lecturers need to create children 's literature?, the problem is "yes". It is because teachers are physically close to children. They understand the children"s various characteristics. Therefore, they need appropriate reading materials for the children in the classroom. Meanwhile, lecturers have the opportunities to conduct a research. They can find appropriate references for the children. Teachers and lecturers may find problems as well as the solutions. Among them is to write fiction for children.

Children needs books that are in accordance with their developmental stages. Children grows along with the development of their intellect, moral, emotion and personality, language, and story concept. The process continues until they fully function as a person or until they can fully actualize themselves. To achieve that, they need to obtain their basic needs, such as the awareness to love and to be loved, the need to understand and to be understood, the need to be recognized as a member of a group, the feeling of being safe and secure, and the freedom to grow and develop.

Children at grade 4 to 6 of elementary school - ranged from 10 to 12 years old - can see abstract relationship among 
objects. They develop their intellect yet they feel inferior. Further, they can see problems in an appropriate point of view. In terms of social relation, they have strong interest in social activity, improve their interest in groups, seek intimacy among group members, adopt the models presented by others rather than their parents, and show their interest in specific activity. In addition, they tend to seek approval and want to impress others, show their ability and willingness to see from other peoplees point of view, look for values, show different characteristics, develop their feeling of justice and care for others, and develop their understanding and acceptance for rules based on gender.

In addition, children at this period can think "scientifically," using theory and arguments as well as testing certain hypothesis. Children can also solve the problem based on their logics. Therefore, the model stories should present daily problem solving materials for the children. They lead children to find and discover cause-and-effect relationship, as well as the implication of the characters.

As for the content, the story needs to present characters at elementary school level, who are facing their particular problems and are trying to solve them according to their way of thinking. Minor characters can be added to help the main characters in solving the problems. What is meant by problems are those that are commonly faced by elementary school children. Author needs to provide interesting and simple title and plot. The setting should be familiar with the children, such as home or school. The language should be adjusted to that of the children. in addition, writers need to master the techniques in writing fiction. The following is the sample of children stories for elementary school children, aged 10-12 years old.

\section{Rambut Keriting Surti Karya Rina Ratih} kekecewaan.

Surti menyisir rambutnya berkali-kali di depan cermin. Setiap pagi, wajahnya cemberut penuh dengan

"Huh selalu begini!" katanya dalam hati. Kali ini dicelupkannya sisir ke dalam air dan rambutnya kembali disisir. Surti masih berdiri di depan cermin menyisir rambut ketika ibu masuk ke kamarnya.

“Ayo sarapan, nanti terlambat sekolah!” ajak ibu. Surti diam saja. "Kenapa?” Tanya ibu lagi. Surti melempar sisirnya karena kesal.

"Selalu begini, Surti kesal sekali, bu!" jawab Surti sambil menarik-narik rambutnya. Ibu tersenyum mengerti mengapa Surti suka cemberut kalau melihat rambut keritingnya di cermin.

"Lihat bu, ini rambut nggak mau lurus. Sebel deh!" kata Surti lagi.

"Sudah, nanti terlambat!" ibu menarik tangan Surti menuju meja makan. dihabiskan.

Di meja makan, ibu masih melihat Surti sarapan dengan setengah hati. Bahkan, sarapannya pun tidak

"Tidak dihabiskan?" Tanya ibu dengan sabar. Surti menggeleng. Rambutnya bergoyang-goyang. Ibu suka melihatnya tetapi Surti tidak menyukainya.

"Hari ini pelajaran olah raga kan? Nanti cape lho. Tenagamu akan terkuras. Baiknya kamu makan yang banyak!" ibu meminta Surti untuk menghabiskan sarapannya.

"Bu..." Tanya Surti sambil menatap ibunya.

"Ya," Ibu membalas menatap Surti penuh kasih sayang.

"Kenapa sih rambut Surti keriting begini padahal rambut ibu lurus?” Tanya Surti polos. Ibu tersenyum dan menatap Surti.

"Karena rambut ayahmu keriting!" jawab ibu sambil tersenyum.

"Selalu itu jawaban ibu." jawab Surti. Ibu tersenyum lagi.

"Tentu dong sayang! Kamu anak ayah dan ibu satu-satunya. Ayolah berangkat sekolah nanti terlambat." Kata ibu sambil beranjak dari meja makan. Surti segera memakai sepatu dan mengeluarkan sepedanya. Surti pamit dan mencium tangan ibu meski wajahnya masih tetap cemberut.

Ibu mengantar Surti ke depan. Ibu melihat Surti segera menggenjot sepedanya menuju sekolah yang tidak jauh jaraknya dari rumah. Dari jauh, ibu melihat rambut Surti yang ikal sebahu melambai-lambai tertiup angin. Rambut ikal yang lebat dan hitam, seperti rambut ayahnya yang sudah meninggal sejak Surti kecil. Ibu menyukai rambut Surti yang indah, lebat, hitam dan ikal itu.

Anak-anak SD kelas lima itu berlari mengitari lapangan beberapa putaran. Surti berada di antara mereka. Keringat mulai membasahi punggung dan dahinya. Karena matahari pagi sudah bersinar, rasa panas mulai menyengat. Setelah berlari, pelajaran dilanjutkan dengan bermain kasti. Wow bukan main capenya. Wajah Surti memerah, keringat membasahi kepala dan dahinya. Begitu juga dengan teman-temannya.

Selesai pelajaran olah raga, Surti beristirahat. Ia bergerombol dengan teman-temannya di bawah pohon pinggir lapangan. 
“Cape sekali ya, badanku keringatan semua!” kata Sisi mengeluh.

"Ya, hari ini lebih gerah dari biasanya!" balas Tuti.

"Rambutku tambah lepek aja nih!" Sisi kembali berkomentar sambil mengibaskan rambutnya yang tipis kemerahan.

"Enaknya diikat saja! Atau pendek sekalian!" Indah menimpali.

"Ya, rambut kita basah jadi lepek gini kecuali rambut Surti ha ha!" Sisi melirik dan mulai meledek. Surti diam saja.

"Eh jangan marah nona manis, itu beneran! Lihat rambutku dan rambut Sisi lepek kayak tikus kehujanan.

Rambutmu? tetap mengembang kayak kue baru keluar dari oven!" kata Sisi sambil menahan senyum.

"Ya persis iklan shampo!" celetuk Arum menambah geram hati Surti.

"Mana ada iklan sampo rambutnya keriting!" ucap Sisi sambil tertawa dan meninggalkan mereka semua.

"Kenapa sih, kamu seneng banget ngurusin rambutku?" Surti naik pitam juga. Ia berdiri menatap Sisi yang sudah pergi. Semua teman Surti yang ada di sana tahu kalau Surti marah kepada Sisi yang selalu usil.

"Sudah, nggak usah dimasukkan hati!" kata Faizah sambil mengajak Surti ke ruang ganti baju.

Surti memang mudah marah dan jengkel tiap kali teman-teman menyinggung rambutnya. Apalagi Sisi, anak orang kaya itu selalu tidak punya perasaan. "Huh....ini rambut bikin hari-hariku sebel saja!" kata Surti dalam hati. Air matanya hampir tumpah tapi Surti menahannnya.

Pulang sekolah, ibu menyambut Surti dengan senyum. Surti membalasnya dengan cemberut. Di kamar, Surti kembali berdiri depan cermin dan memandang rambut keritingnya dengan kesal. "Ihhh ini rambut kenapa sih kamu keriting? Digerai jelek, diikat apalagi!" sambil disisirnya berulang-ulang. Diambilnya karet rambut dan diikatnya kuat-kuat. Pipinya jadi kelihatan tembem. "Aku mau potong pendek saja!" tekad Surti.

Surti segera ke ruang tengah. Tampak ibunya sedang menata kue kue kering ke dalam toples. Aroma kue lezat tercium ke semua sudut rumah Surti. Ia mendekati ibunya dan menceritakan kejadian siang tadi di sekolah.

"Aku mau potong rambut saja bu, pendek sekalian. Sore ini ya?!" kata Surti datar.

"Potong? Yakin?" mata ibu menyelidik. Ibu menatap Surti dan sejenak menghentikan tangannya yang sedang memasukkan kue kue ke dalam toples. Ibu tahu Surti mudah tersinggung jika berurusan dengan rambutnya. Ibu sadar, Surti sedang dalam puncak kemarahan karena masalah rambut dan ledekan teman-teman sekolahnya.

"Baiklah nanti ibu antar. Kenapa tiba-tiba?" dahi ibu berkerut. Tidak biasanya Surti begitu.

"Sudah nggak tahan diledek terus!” jawab Surti ketus. $* * *$

Sore itu, Surti dengan ibunya mengantar kue-kue pesanan bu Wawan sebelum akhirnya ke salon sederhana di ujung desa itu.

"Dipotong model apa, neng?" Tanya Bu Prapti, pemilik salon. Surti menatap ibunya melalui cermin. Ibu tersenyum menyerahkan keputusan pada anaknya.

"Hmmmm dipotong model apa saja. Pendek juga boleh. Yang penting lurus!" jawab Surti. Bu Prapti pemilik salon itu tersenyum. Ibu juga tersenyum geli mendengarnya.

"Kalau lurus banget ya nggak bisa neng. Sudah dari sananya keriting!” kata Bu Prapti sambil menyisir rambut Surti.

"Hmmm dirapihkan saja ya? Biar tambah cantik? Kalau pendek nanti mukanya tambah kelihatan bulat, neng!" Bu Prapti menjelaskan. Surti kecewa tapi akhirnya mengangguk juga. Selesai dipotong, rambut Surti tampak lebih tertata. Wajahnya kelihatan lebih manis. Tapi...ooo rambutnya tetap tidak lurus seperti yang diinginkannya.

"Sudah neng! Tuh kan lebih rapih dan manis!" kata bu Prapti selesai memotong rambut Surti. Benar saja, Surti melihat wajahnya di cermin tampak lebih manis dari biasanya. Mungkin karena rambutnya menjadi lebih rapih. Ibu mengusap kepalanya dan tersenyum sambil memandang kepada Surti,

"Sur, rambutmu itu indah! Karunia dari Allah, warisan dari ayahmu satu-satunya!" kata ibu sambil tersenyum. Surti sangat merindukan ayahnya.

$* * * *$

"Potong nih yeeee!". Sisi yang pertama memberi komentar pagi itu. Disusul komentar dan lirikan teman-temannya yang biasa menggoda.

"Wah sekarang sudah persis iklan shampo!" celetuk Arum.

“Tetep saja keriting!” suara Sisi lagi. Kali ini Surti menahan diri untuk tidak marah. Ingat perkataan ibu kemarin sepulang dari salon. Waktu itu, di kamar Surti, ibu memeluknya dari belakang dan berdiri di depan cermin.

"Surti, lihatlah! Kamu tidak perlu malu karena rambut yang keriting. Allah memberi kelebihan pada setiap manusia. Kalau orang lain mungkin diberi kelebihan kulit yang putih bersih, atau alis yang hitam tebal, gigi yang rapih, badan yang tinggi, maka Surti diberi kelebihan rambut yang keriting." Kata ibu hati-hati.

"Kelebihan bu?" Surti mengernyitkan dahi. Masih berdiri depan cermin.

"Ya itu namanya kelebihan. Coba Surti lihat, banyak orang yang rambutnya tipis, kemerahan, mudah rontok, mudah patah kan? Apakah rambutmu tipis, kemerahan? Tidak kan? Apakah rambutmu sering rontok, mudah patah? Tidak juga kan?" Tatap ibu tajam. Surti menggeleng. 
"Nah jadi kenapa Surti membenci rambut sendiri? Padahal Allah memberimu rambut yang lebat dan kuat seperti rambut ayahmu. Apa Surti lebih suka tidak punya rambut?" Tanya ibu lagi. Surti menggeleng. Ibu tersenyum. Benar kata ibu, seharusnya aku bersyukur diberi rambut keriting yang hitam dan lebat. Bukan membencinya. Terbayang bagaimana Sisi berambut tipis dan kemerahan. Begitu juga teman lainnya, kepanasan dan kena keringat sedikit saja saat berolah raga, rambutnya lepek.

"Jadi? Tidak usah marah atau jengkel apabila ada teman-teman yang membicarakan rambutmu. Oke? Janji?" ibu menatap Surti dan Surti pun mengangguk. Surti sudah janji kepada ibunya untuk tidak marah dan jengkel lagi. Makanya, Surti diam saja ketika Sisi terus menggodanya.

Di kelas, Sisi heran melihat Surti tenang-tenang saja. Padahal biasanya kalau Sisi meledek rambutnya, Surti cemberut. Justru Sisi yang usil menjadi tambah senang menggodanya. Faizah yang duduk di sebelah Surti juga heran. Guru kelas belum datang.

"Potong rambut model baru nii yeee!" Sisi meledek lagi. Berharap Surti cemberut sambil memandang padanya. Akan tetapi, kali ini Sisi salah. Surti tidak cemberut bahkan tidak memandang kepadanya. Surti asyik membaca buku sambil menunggu bu guru Syifa datang. Faizah yang duduk sebangku dengan Surti pun agak heran.

"Tumben Sur, kamu nggak marah sama Sisi!” kata Faizah berbisik. Surti memandang sahabatnya, Faizah.

"Biarin saja!" jawab Surti singkat.

"Biasanya kamu marah?" Tanya Faizah lagi.

"Nanti juga cape sendiri!" Jawab Surti lagi singkat.

"Wow kamu sekarang percaya diri setelah dipotong ya?" Faizah penasaran. Surti mengangguk sambil tersenyum kecil.

"Ya. Tahu nggak kenapa?" Tanya Surti. Faizah menggeleng.

"Kenapa, Sur?" Tanya Faizah penasaran.

"Ini warisan ayahku satu satunya!" kata Surti sambil menggoyang-goyangkan kepalanya. Faizah tersenyum dibuatnya. Dia senang melihat Surti tidak lagi cemberut gara-gara rambut keritingnya. Hmmmm Surti juga merasa lega mengatakan bahwa rambut keritingnya adalah warisan ayahnya. Surti sekali lagi menggoyangkan kepalanya dan merasakan gerakan lembut di seluruh rambutnya! Kali ini Faizah dan Surti tertawa bersama. "Ini warisan ayahku, dan aku harus merawatnya!” janjinya dalam hati.

Yogyakarta, 2 April 2018

The short story, entitled "Rambut Keriting Surti" tells us about the main character, Surti. She has a problem with her hair. She is always upset before going to school every day. At school, her friends tease her because of her curly hair. This problem is common for Indonesian kids. Other characters are a wise mother, a best friend named Faizah, and Surties school friends. The mother, an adult female, becomes the character who has many experiences in life. She tries to convince Surti that her curly hair is the blessings from Allah. She is a wise character that helps Surti to think with her reasonings.

The setting takes place at school, where various events happen to test the emotion of the main character, Surti. Through the problems, a child goes through a process and develops self-actualization. By the help of mother and Faizah, Surti, who was previously inferior and emotional transforms into a fully confidence one. This is the process of understanding and of the ability to seek the values of life. A child's awareness arises when the characters realizes the causes of her curly hair. That is a process of acceptance and awareness that every human is different. Other awareness also comes up when the character cannot hold her emotions, leading her to a "weak" position. And at the end, she develop scientific and logical skills in finding the best solution for the problems she has.

\section{CONCLUSION}

Teachers or lecturers need to write children's stories that help to assist the children along their growth. This is significant, for teachers are close to children, while lecturers, serving as researchers, concern with literature and know much about references relevant to children "s developmental stages. The skills of writing fiction for children can be learned as long as these people are willing and are able to manage their time. The process will result in the abundant reading materials for children, written by either men of letters or teachers and lecturers.

Children story entitled "Rambut Keriting Surti" was written after learning Bradyes children's developmental stages. It is about a girl who was inferior at first and isolate herself from the community for she was less confident in the social activities. However, she finally shows her ability in seeking the values, the awareness of differences among individuals, understanding and acceptance of the rules that are based on gender. At this stage, a child is able to think about the abstract ideas, think scientifically and theoretically. She also can deliver her arguments and test the hypothesis emphasizing on the thinking skills. Children at this period can also solve the problem logically by engaging relevant matters. 
The story is not the best one, but at least the writer, who is also a lecturer, has tried to create a model for children's stories that are relevant to their developmental stages, particularly the intellectual, emotional, and personal developments.

\section{References}

Brady, L. (1991). "Children and Their Books: The Right Book for The Right Child 1", in Maurice Saxby \& Gordon Winch (eds). Give Them Wings, The Experience of Children's Literature, Melbourne: The Macmillan Company, hlm. 26-38.

Brown, DH. (2000). Principles of Language Learning and Teaching. New York: Addison WEsly Longman.

Edwards, PA. (2004). Children's Literary Development, Boston: Pearson.

Huck, CS, S., Hepler, \& J. Hickman. 1987. Children's Literature in The Elementary School. New York: Holt, Rinehart and Winston.

Nurgiyantoro, B. (2005). "Tahapan Perkemabanngan Anak dan Pemilihan Bacaan Sastra Anak" dalam Cakrawala Pendidikan. Juni Tahun 2005, Th,XXiV. No 2.

Nurgiyantoro, B. (2005). Sastra Anak. Yogyakarta: Gadjah Mada University Press.

Rampan, CL. (2003). "Dasar-Dasar Penulisan Cerita Anak" dalam Teknik Menulis Cerita Anak, ed. Sabrur R. Soenardi. Yogyakarta: Pinkbook.

Ratih, R. (2016). "Menulis Cerita Anak: Menanam Kata Berbuah Karya” in Sastra Anak. Yogyakarta: HISKI BBY

Ratih, R, (2018). Surti, Mawar, dan Kupu-Kupu. Yogyakarta: Buana Grafika.

Ratih, R, (2016). Lebah Lebay di Taman Larangan. Yogyakarta: Pustaka Pelajar.

Resmini, Novi, Dadan Djuanda \& Isah Cahyani, (2006). Pembinaan dan Pengembangan Bahasa dan Sastra Indonesia. Bandung: UPI PRESS.

Sarumpaet, RKT. (2003). "Struktur Bacaan Anak" in Teknik Menulis Cerita Anak, (ed. Sabrur R. Soenardi). Yogyakarta: Pinkbook.

Saxby, M \& G. Winch, (1991). Give Then Wings, The Experience of Children's Literature. Melbourne: The Macmillan Company.

Sugihastuti, (2015). "Bacaan Anak: Salah Satu Penangkal Pengaruh Negatif Acara TV" in Pelangi Sastra Anak. Yogyakarta. A.Com. Advertisting.

Sugihastuti, (2015). "Memaknai Lebah Lebay di Taman Larangan Karya Rina Ratih" in Pelangi Sastra Anak. Yogyakarta. A.Com. Advertisting. 